Uniwersytet Gdański

\author{
Henryk Woźniak
}

\title{
PRODUKTY HYBRYDOWE JAKO WYZWANIE DLA LOGISTYKI
}

Z arys treści. Logistyka musi dostosowywać się do zmieniających się warunków gospodarowania, przede wszystkim musi stać się skutecznym narzędziem wspierającym konkurencyjność przedsiębiorstw na coraz trudniejszym międzynarodowym rynku. Celem prezentowanego artykułu jest ukazanie możliwości wspierania konkurencyjności przedsiębiorstw produkcyjnych poprzez rozwijanie i stosowanie w praktyce koncepcji produktów hybrydowych. Stanowią one wyższy poziom obsługi klientów, oferując im rozwiązywanie indywidualnych problemów związanych z zakupem i wykorzystaniem produktów w określonych realiach rynkowych. Wymaga to zupełnie nowego podejścia producentów do kształtowania relacji z klientami.

Słow a kluc z ow e : obsługa klientów, pakiet usług, produkty hybrydowe, hybrydowe tworzenie wartości, logistyka.

\section{WSTĘP}

Konkurencja przedsiębiorstw produkcyjnych napotyka coraz większe trudności na rynku. Kształtowanie strategii rynkowych jedynie poprzez różnicowanie dóbr fizycznych staje się narastająco uciążliwe. Produkty o tych samych lub podobnych walorach użytkowych i właściwościach mogą być współcześnie wytwarzane na całym świecie przez wielu oferentów rynkowych, często po bardzo niskich kosztach. Wyłącznie z samej produkcji przedsiębiorstwa mogą się utrzymywać na rynku tylko w ograniczonym zakresie. Skutkiem tego może być (częściowo rujnująca) konkurencja cenowa, prowadząca do istotnego kurczenia się marż producenckich na wielu rynkach produktów, co odnotowuje się w ostatnich latach coraz częściej. Dla producentów możliwym wyjściem z tej sytuacji jest dostarczanie portfolio produktów w formie tzw. produktów hybrydowych. Chodzi tutaj 
o zintegrowaną wiązkę usług składającą się z dóbr rzeczowych i towarzyszących im usług niematerialnych, mającą na celu rozwiązywanie problemów specyficznych dla danej grupy klientów. Istotę oferty stanowi, jak twierdzą J. Becker i H. Krcmar, skoncentrowanie się na całościowym, kompleksowym wytworzeniu konkretnych korzyści dla nabywców (Becker, Krcmar, 2008, s. 169-179). Zmieniające się preferencje klientów i ich zindywidualizowane, często niepowtarzalne życzenia, wymuszają zatem zmianę zachowań rynkowych przedsiębiorstw przemysłowych, polegających na oferowaniu zamiast produktu, rozwiązywania ich zróżnicowanych problemów. W miejsce czystego transferu rynkowego maszyny bądź urządzenia, które stanowią tradycyjnie istotę oferty przemysłowej, występują zintegrowane wiązki usług, skoncentrowane na rozwiązywaniu problemów u klientów, składające się z hardwaru i softwaru, wraz z niezbędnymi usługami towarzyszącymi. W przyszłości należy zatem liczyć się z takimi zmianami, że wyizolowane, tradycyjne oferty usług rzeczowych nie będą zgodne $\mathrm{z}$ rosnącymi wymaganiami klientów na rynkach B2B, co pod znakiem zapytania postawić może zdolność konkurencyjną określonych grup producentów-oferentów. Zdaniem G. Ernsta, w miejsce tradycyjnej sprzedaży, przykładowo urządzeń z branży IT, ze względu na różnicowanie strategii konkurencyjnych oferowane będą w coraz większym stopniu indywidualnie zaprojektowane kombinacje usług hard- i softwarowych, w powiązaniu z uzupełniającymi usługami (Ernst, 2007, s. 10). Podczas gdy podstawowy produkt materialny rozwijać się może w kierunku imitacyjnego, standardowego, a zatem łatwo wymienialnego dobra, w niematerialnych częściach składowych kompleksowych rozwiązań upatruje się decydującej możliwości dla różnicowania konkurencji (Nippa, Wienhold, 2007, s. 1-2). W optymalnym przypadku stosowanie takich rozwiązań może znacząco ułatwić przejęcie przywództwa w zakresie stosowania pożądanych rozwiązań systemowych na rynku i uzyskanie przewagi konkurencyjnej.

\section{ISTOTA PRODUKTÓW HYBRYDOWYCH}

Dane statystyczne w wielu krajach, szczególnie wysoko uprzemysłowionych, wskazują na sukcesywny spadek wielkości zatrudnienia w przemyśle i wzrost zatrudnienia w sektorze usług. W tym kontekście niektórzy autorzy twierdzą wręcz o postępującej tertiaryzacji produkcji dóbr rzeczowych, inni zaś podkreślają zmiany jakościowe w podziale pracy w obrębie sektora, jakim jest przemysł. Przyczyn tego zjawiska należy upatrywać także w zróżnicowanych poziomach rentowności sfery czysto produkcyjnej i usługowej. Obsługa serwisowa w przemyśle okazuje się zdecydowanie bardziej rentowna niż rentowność sprzedaży wyrobów gotowych (maszyn, linii technologicznych itp.). 
W warunkach intensyfikacji konkurencji i koncentracji na kluczowych kompetencjach, w przypadku klientów przedsiębiorstw przemysłowych, obserwuje się zachowania polegające na oczekiwaniu przez nich na systemowe rozwiązywanie określonych problemów przez dostawców, zamiast rozdzielnego pozyskiwania określonych usług rzeczowych bądź niematerialnych. Ta zmiana orientacji na rozwiązywanie problemów, specyficzne dla konkretnych klientów, przy których usługi materialne ,stapiają się niejako bezpośrednio z innymi rodzajami świadczonych bądź oczekiwanych usług, prowadzi do kreowania nowych rodzajów ofert usługowych i warunkuje nowe procesy ich rozwoju i realizacji. Zacierające się granice pomiędzy produktami i usługami dostarczanymi dla klientów pozwalają na thumaczenie charakteru tych zmian jako przejście od koncepcji „produktu hybrydowego" do koncepcji „hybrydowego tworzenia wartości”.

Pojęcie „produkt hybrydowy” pojawiło się pierwszy raz w roku 1997 na konferencji poświęconej rozwojowi sektora usług. H.-J. Bullinger opisał wtedy „produkt hybrydowy” jako przyszłościowy model powiązania produktów materialnych i usług, akcentując efekt „synergii produktu i usługi” w kontekście zarządzania klientami (H.-J. Bullinger, 1997, s. 27-64). W roku 1999 ten sam autor twierdził o wdrażaniu usług hybrydowych jako uzupełnieniu dla usług materialnych, a inni wskazywali na konieczność zapewnienia pozycji konkurencyjnej przedsiębiorstw poprzez wdrażanie ,innowacyjnych produktów hybrydowych” (Bullinger 1999, s. 49-64). W roku 2000 M. Korell i W. Ganz dokonali rozróżnienia między usługami towarzyszącymi zbywaniu produktów materialnych a hybrydowym tworzeniem wartości, pisząc; „można rozróżnić dwa zasadnicze punkty widzenia, dlaczego przedsiębiorstwo przemysłowe zajmuje się problemem usług: po pierwsze, przedsiębiorstwo rozwija w sposób celowy usługi jako uzupełnienie dla jego wyrobów finalnych. W tym przypadku produkt materialny zajmuje $\mathrm{w}$ dalszym ciągu centralne miejsce w polityce zbytu. $Z$ drugiej zaś strony przedsiębiorstwo samo rozwija się, przekształcając swój profil «czystego producenta» na profil usługodawcy, względnie podmiotu będącego w stanie rozwiązać złożone problemy klientów. Pierwotny produkt materialny staje się w tym przypadku tylko częścią usługi, natomiast usługa staje się właściwym produktem. Ponieważ produkt fizyczny w wielu przypadkach jest tylko środkiem do uzyskania celu, a właściwym celem jest rozwiązanie problemów klienta, to właśnie usługa polega na rozwiązaniu konkretnego problemu" (Korell, Ganz, 2000, s. 153).

Dla oferenta produktów, wraz z przejściem do roli oferenta rozwiązań konkretnych problemów, dochodzi do zmiany formy stosunków między podmiotami na rynku, a mianowicie przejście ze stosunków transakcyjnych na stosunki relacyjne z klientami. Oznacza to w konsekwencji wymóg zmiany struktur organizacyjnych, w której na ważności zyskują rozwiązania o charakterze procesowym. Transformacja w kierunku rozwiązywania problemów klientów przy 
wykorzystaniu produktów hybrydowych wymaga ponadto rozwiązania innego problemu; głównym czynnikiem sukcesu staje się powiązanie kompetencji związanych z rozwojem i implementacją kompleksowych rozwiązań właściwych dla konkretnego klienta, względnie grupy klientów, z kompetencjami dotyczącymi rozwoju i wytwarzania powtarzalnych, skalowalnych ${ }^{1}$ produktów lub usług. W tym też kontekście realizacja usług polegających na rozwiązywaniu problemów u klientów za pomocą produktów hybrydowych wymaga ukształtowania struktury organizacyjnej zorientowanej na odbiorców, dzięki której oferent może uzyskać lepsze zrozumienie ich specyficznych wymagań oraz istoty problemów. Stawia to wszystkie strony, w tym oferentów softwaru, przed dużym wyzwaniem (Westschalffung..., 2007, s. 7).

Z uwagi na zróżnicowany charakter produktów hybrydowych w literaturze podjęto próbę ich typologizacji za pomocą czterech różnych, ale istotnych cech. Wykorzystano te cechy, które mogą być pomocne przy ocenie implementacji produktów hybrydowych (Nippa, Wienhold, Piezonka, 2007):

1. Ilość i heterogeniczność usług cząstkowych. Produkty hybrydowe charakteryzują się występowaniem kombinacji różnych usług cząstkowych. Im większy jest zakres i zróżnicowanie tych poszczególnych usług cząstkowych, tym wyższa jest kompleksowość wytworzenia pakietu usług. Rośnie również złożoność logistycznej obsługi klienta.

2. Integracja usług cząstkowych. Podkreślić należy integratywny sposób traktowania i analizy produktów rzeczowych i towarzyszących im usług, który wykracza poza ich proste powiązanie i który w przyszłości stanie się krytycznym czynnikiem sukcesu nie tylko w odniesieniu do wytwarzania usług, lecz także dla ich zbywania na rynku. Stopień integracji jest ograniczony, gdy poszczególne usługi cząstkowe są relatywnie od siebie niezależne, a klienci mogą je bez problemu substytuować przez usługi cząstkowe innych oferentów. W ekstremalnym przypadku poszczególne komponenty są ze sobą funkcjonalnie tak mocno powiązane, że ich użycie może być w pełni wykorzystane tylko we wzajemnej kombinacji.

3. Stopień indywidualizacji. Ponieważ zadaniem produktów hybrydowych jest rozwiązanie problemów klientów w celu zapewnienia im indywidualnych korzyści, to konieczne jest zestawianie w pakiety

1 Skalowalność (Scalability) oznacza zdolność produktu do funkcjonowania po jego rozbudowie mającej na celu powiększenie parametrów, bez jednoczesnego pogorszenia innych parametrów (por. www.storagefocus.pl/slownik/skalowalnosc-). W odniesieniu do produktów informatycznych skalowalność oznacza, jak produkt będzie działał, gdy wzrośnie liczba użytkowników i objętość danych (por. Subieta). 
poszczególnych usług cząstkowych w sposób specyficzny dla różnych klientów. Z ograniczonym stopniem indywidualizacji mamy do czynienia wtedy, gdy występuje specyficzna dla klientów konfiguracja usług standardowych. Jeżeli natomiast usługi cząstkowe są przygotowywane i wytwarzane $z$ uwagi na specyficzne wymagania klientów, to sytuacja taka oznacza wysoki stopień indywidualizacji. Dostosowanie produktu hybrydowego do specyficznych oczekiwań czy życzeń klientów wymaga integracji klientów w procesy wytwarzania usług. Dla logistyki oznacza to konieczność segmentacji obsługi oraz kształtowania efektywnych systemów klasy CRM (Customer Relationship Management).

4. Wymiar czasowy wytwarzania usług. Usługi cząstkowe ukierunkowane na rozwiązywanie złożonych problemów klientów realizowane są często wzdłuż całkowitego custome-activity chain względnie consumption chain. Wytwarzanie usług $\mathrm{i}$ interakcje $\mathrm{z}$ klientem $\mathrm{w}$ przypadku produktu hybrydowego mają z reguły dłuższy wymiar czasowy niż w przypadku stand-alone-products. Oznacza to, że w trakcie wytwarzania usług może dochodzić do zmian i działań dostosowawczych, co prowadzi w sposób naturalny do wzrostu kompleksowości usług. Zwiększona kompleksowość produktu hybrydowego zmusza do konieczności wykazania się przez pracowników sfery zbytu kompleksową wiedzą o produktach i całym spektrum możliwych do wykonania usług - nie tylko w ramach własnego przedsiębiorstwa, ale także w odniesieniu do partnerów kooperacji rynkowej. Szczególne wymagania adresowane są tutaj do pozyskania i przetwarzania właściwych informacji przez pracowników sfery zbytu i logistyki. Istnieje zatem konieczność modyfikacji systemów motywacyjnych i systemów wynagradzania w sferze zbytu i logistycznej obsługi klientów.

Profilowanie procesów konkurencji poprzez oferowanie produktów hybrydowych wymaga wiedzy i zrozumienia ich wartości pożądanej przez klientów. W przypadku przemysłowych decyzji w sferze zaopatrzenia ma to kluczowe znaczenie. $Z$ uwagi na dużą intensywność konkurencji w wielu branżach gospodarki, począwszy od technologii informatycznych i telekomunikacyjnych, poprzez budowę maszyn i urządzeń, a skończywszy na usługach finansowych, wiele przedsiębiorstw oczekuje korzyści konkurencyjnych w wyniku wdrożenia i skutecznego urynkowienia oferty, jaką stanowi zintegrowana kombinacja dóbr rzeczowych i usług (Schmitz, 2008).

Wdrożenie nowego modelu biznesowego opartego na usługach związane jest z dużym ryzykiem dla obu stron transakcji, mimo że stwarza również szansę odróżnienia się od konkurentów, szansę na silniejsze powiązanie z klientami oraz 
uruchomienie nowego potencjału rozwoju i dodatkowych przychodów. Przed wdrożeniem tego modelu należy jednak uporządkować kilka istotnych kwestii, aby mógł on dostarczać korzyści obu partnerom w zbliżonym stopniu. Problemami wymagającymi uzgodnień przez komórki logistyki i marketingu obu stron rynkowych są z pewnością (www.business-wissen.de/z 16.10.2008):

1. Zarządzanie procesami (oferent i klient muszą dokonać wspólnie precyzyjnej analizy procesów, aby zdefiniować usługę potrzebną i korzystną dla klienta).

2. Zarządzanie cyklem życia (uwzględnienie cyklu życia produktu jest warunkiem prawidłowego konstruowania produktów oraz właściwego szacowania kosztów i dochodów). Mogą tutaj znaleźć zastosowanie logistyczna koncepcja rachunku kosztów cyklu życia produktu² (Life Cycle Costing) oraz strategia Design to Costs ${ }^{3}$.

3. Dostosowanie produktu (nie chodzi o optymalną sprzedaż produktu, lecz o jego optymalną eksploatację; na znaczeniu zyskuje trwałość, prostota obsługi i elastyczność oprzyrządowania oraz możliwość ponownego wykorzystania).

4. Właściwe ustalenie kosztów (jest to trudny element, wymagający przeniesienia części ryzyka eksploatacyjnego na klienta). Stosowana w przemyśle motoryzacyjnym logistyczna koncepcja Target Costing może być w pewnym stopniu pomocna $\mathrm{w}$ rozwiązaniu tego problemu.

5. Zasady tworzenia cen za usługę (należy poruszać się w przedziale między kwotą - marżą - pokrycia kosztów u oferenta a możliwym poziomem oszczędności kosztów u klienta).

6. Działania dostosowawcze i optymalizujące (im dłużej oferta jest akceptowana na rynku i im więcej znajdzie nabywców, tym bardziej można dostosować ją do oczekiwań klientów i poprawić wynik finansowy, co jest efektem skali i uczenia się).

2 W literaturze przedmiotu można znaleźć szczegółowe opracowania na ten temat, przykładowo; Rachunek kosztów cyklu życia produktu w zarządzaniu przedsiębiorstwem. Praca pod red. R. Kowalaka. Uniwersytet Ekonomiczny we Wrocławiu, 2009.

3 W przypadku stosowania strategii Design to Costs zespoły złożone z przedstawicieli badań i rozwoju oraz zakupów, reprezentujących partnerów rynkowych (dostawcy, odbiorcy, kooperanci) identyfikują wspólnie możliwości zmiany wzorów produktów (design) oraz specyfikacji części i komponentów przy zapewnieniu synchronizacji procesów projektowania oraz technologii produkcyjnych. Celem tych działań jest korzystniejsza kosztowo produkcja, względnie korzystniejszy zakup podzespołów, niepowodujący przy tym ograniczenia jakości tych elementów (por. Woźniak, 2008, s. 19, odsyłacz 11). 
7. Przygotowanie i realizacja umowy wykonania usługi (przyrzeczenie wykonania usługi wymaga często szczegółowych ustaleń dotyczących kwestii związanych z ryzykiem, w szczególności możliwości jego skalkulowania).

Tymczasem w nieznoszącej próżni praktyce obserwuje się powolne, ale zauważalne przechodzenie części firm do funkcji „,podmiotu rozwiązującego problemy klientów". Potwierdza się również w praktyce fakt, że taka opcja dla wielu firm oznacza często - z wielu względów - cel niemożliwy do realizacji. Przejście do hybrydowego procesu tworzenia wartości zaczyna się zwykle od oferowania „usług towarzyszących produktom”. W literaturze wskazuje się na ograniczone wykorzystanie istniejącego potencjału w tym zakresie usług. Do grupy tej zaliczyć można oferty szkolenia personelu, nadzoru eksploatacyjnego, obsługi maszyn i urządzeń, ale również usługi inżynieryjne, tzw.,,model samodzielnego wykonawcy", usługi finansowe, wtórny odzysk lub procesy utylizacji. Na możliwe i rzeczywiste przypadki zastosowania wymienionych rozwiązań wskazać można w wielu branżach. Przykładowo, w zarządzaniu nieruchomościami (Facility-Management) wykorzystuje się różne techniki sterowania, urządzenia wykorzystywane $\mathrm{w}$ medycynie przygotowywane są zgodnie $\mathrm{z}$ indywidualnymi życzeniami dostosowanymi do programów leczenia lub rehabilitacji, producenci maszyn i urządzeń wypożyczają maszyny wraz w personelem eksploatacyjnym i obsługowym. W tym miejscu należy wymienić pierwszy, bardzo ważny model organizacyjny takiego rozwiązania z roku 2005, zwany „modelem samodzielnego wykonawcy" (Pay on Production, w jęz. niem. Betreibermodell). Został on wykorzystany dotychczas w przemyśle motoryzacyjnym, ale również w przemyśle budowy maszyn, przede wszystkim w przemyśle elektrotechnicznym i produkcji urządzeń dla przemysłu dóbr konsumpcyjnych, np. do produkcji telefonów komórkowych; generalnie w produkcji dla niestabilnych rynków. Istnieją możliwości stosowania różnych wariantów modelu Pay on Production, w których producent maszyn nie tylko je wytwarza, ale również później eksploatuje. Zdaniem $\mathrm{H}$. Wildemanna mogą to być rozwiązania mające na celu wyłącznie zakup usługi „dysponowania” maszyną czy linią produkcyjną, zwany wariantem Pay on Availability (Wildemann, 2004, s. 4); modele, których celem jest polepszenie produktywności urządzenia poprzez przejęcie i użytkowanie środków produkcyjnych i zarządzanie jego eksploatacją, jak również warianty, mające na celu zmianę i ulepszenie wytwarzanych produktów poprzez innowacje w procesach technologicznych urządzenia bądź grupy urządzeń. Istotne jest to, czy takie rozwiązanie dotyczy kluczowych procesów tworzenia wartości w firmie czy procesów peryferyjnych. Przykładem obszarów kluczowych stosowania modelu mogą być wydziały karoserii czy lakierowania w przemyśle motoryzacyjnym. 
W tym przypadku wytwórca urządzeń eksploatuje swoje własne urządzenia i jest wynagradzany za liczbę wyprodukowanych jednostek. W przypadku obszarów peryferyjnych odnotować można wykorzystanie usług kompresorów, zamiast ich kupna. Chodzi zatem generalnie o zakres zadań i stopień powiązań procesowych między partnerami ${ }^{4}$.

Niemiecki Fraunhofer Institut für System- und Innovationsforschung (ISI) analizuje od kilku lat wdrożenia modelu Pay on Production w gospodarce. Analitycy upatrują w jego zastosowaniu szansę na wzrost konkurencyjności firm oferentów dóbr inwestycyjnych. W szczególności koncerny samochodowe wywierają presję na część swoich dostawców urządzeń, aby zamienić zakup linii technologicznych na opłatę z tytułu ich użytkowania (Lay, 2003, s. 5-7). Na przykład firma KUKA SYSTEMS wdrożyła w roku 2008 taki model do produkcji karoserii do Jeepa Wranglera w zakładach Chryslera w Toledo/Ohio i przejęła finansowanie linii technologicznej (www.kuka.com/res/media/geschaeftsberichte/.../kuka-systems.html.

Ruland wymienił ważne organizacyjne etapy przy oferowaniu produktów hybrydowych. Wyróżnia on trzy nakładające się klasy integracji produktu i usług (za: Ernst, 2007). Do klasy pierwszej zalicza proste usługi odnoszące się do produktu (przykład: software z treningiem). Do klasy drugiej zalicza usługi zwiększające sprawność produktów; są to zintegrowane, skoncentrowane na produkcie rozwiązania (np. utrzymanie sprawności eksploatacyjnej w przypadku silników lotniczych wraz z obsługami gwarancyjnymi). W trzeciej klasie oferowane są natomiast usługi pozwalające optymalizować procesy, czyli jest to konkretnie „szyte na miarę" rozwiązywanie problemów biznesowych (np. producent przejmuje pełną eksploatację, planowanie rozwoju, design oraz rozbudowę infrastruktury sieci komórkowej). Przejście na wyższy stopień klasy usług wymaga zatem zasadniczych zmian $\mathrm{w}$ organizacji przedsiębiorstwa, w kształtowaniu procesów i w odniesieniu do niezbędnych zasobów technicznych oraz personalnych. Na pierwszym stopniu decydująca jest wiedza o produkcie. Prawdopodobieństwo konfliktów między produktem i usługami jest ograniczone, ponieważ odpowiedzialność za produkt jest decydująca. Na stopniu drugim odpowiedzialność za produkt wiąże ze sobą dwa obszary rozwoju obu podmiotów. Istnieją jednak różnorodne kultury, systemy zachęt i mierniki charakteryzujące usługi. Koncentracja uwagi dotyczy jednak nadal linii kształtowania produktu. Na stopniu trzecim koordynacja następuje poprzez wydziały zbytu i marketingu oferenta i nabywcy. Producent staje się „oferentem produktu hybrydowego”. Mimo istnienia odrębnej kultury przedsiębiorstw, odpowiedzialność za produkt przekształca się w odpowiedzialność za pakiet usług.

4 Por.: Horst Wildemann, s. 2. 


\section{PRZYKŁADY KREOWANIA PRODUKTÓW HYBRYDOWYCH W PRZEMYŚLE}

Od pewnego czasu na rynku dostępne są ciekawe oferty produktów hybrydowych, uzyskane dzięki współpracy firm zainteresowanych wejściem na rynek z nowymi, konkurencyjnymi rozwiązaniami (Moeslein, Koelling, 2007, s. 6-9). Produkty takie powstały, między innymi, jako efekt interaktywnego hybrydowego tworzenia wartości w obszarze sportu, zdrowia i fitness, zwanego pod nazwą projektu SPRINT, wspieranego przez Federalne Ministerstwo Kształcenia i Badań (www.projekt-sprint.de).

Projekt SPRINT rozwinął metody, modele i narzędzia dla zapewnienia designu produktów hybrydowych w obszarach sportu, zdrowia i fitness, pilotując je, w celu osiągnięcia wyższego stopnia rozwoju usługodawców i producentów urządzeń jako kompleksowych oferentów konkretnych rozwiązań dla użytkowników. Uruchomiono przy tym dwie ścieżki badawczo-wdrożeniowe; z jednej strony zaproponowano wdrożenie zupełnie nowej usługi hybrydowej. Wspierający zdrowie hybrydowy Personal Health Manager, to po prostu zindywidualizowany coaching w sferze zdrowia. Służy on wdrożeniu indywidualnych programów zdrowotnych za pomocą mobilnych, zintegrowanych i kooperacyjnych systemów informatycznych. System mógłby zostać wykorzystany przez dowolne przedsiębiorstwo dla polepszenia jakości życia i sprawności swoich pracowników lub przez firmę usługową, np. studio fitness. Wysoki poziom innowacyjności menedżera ds. zdrowia polega na inteligentnym połączeniu produktu (urządzenia fitness, zegary do mierzenia tętna, mobilne dodatki etc.) z elementami usługowymi (czynności i usługi związane z obsługą, plany treningowe etc.) poprzez cały cykl życia produktu. Dostarcza on kompleksowego, dostosowanego do konkretnego użytkownika programu sportowego, żywieniowego lub promującego określony styl życia, rozwiązania opartego na wysokiej jakości sprzęcie i niezbędnych urządzeniach towarzyszących.

Druga ścieżka projektu SPRINT doprowadziła do utworzenia centrum kompetencji hybrydowego tworzenia wartości, którego zadaniem jest empiryczna analiza różnych przypadków skutecznego rozwijania, wytwarzania i wprowadzania na rynek hybrydowych pakietów usługowych, by następnie propagować je w formie dobrych praktyk. Przedstawione niżej dwa przykłady interaktywnego tworzenia wartości usług hybrydowych wskazują na znaczący potencjał innowacyjny rozwiązań i jednocześnie na nowe wyzwania dla zarządzania logistyką w łańcuchach dostaw. Przykładami takimi są:

- Wspólna oferta firm Adidas i Polar,

- Wspólny produkt firm Nike i Apple. 
Z innowacją zwaną „fuzja” firmy Adidas i Polar weszły w roku 2006 na rynek ze wspólna ofertą, która stanowiła kombinację - używanych w biegach $\mathrm{w}$ postaci zintegrowanego treningu biegowego. Partnerami kooperacji w celu stworzenia hybrydowej wiązki usługowej były: niemiecki Polar Electro GmbH, córka fińskiego koncernu Polar Electro Oy i Adidas AG z siedzibą w Herzogenaurach.

System treningowy „fuzja” integruje oferty produktowe obu firm we wspólnym rozwiązaniu pakietowym. Pierwotnie wytworzony sensor Polara do mierzenia pracy serca jest zintegrowany bezpośrednio z kolekcją odzieżową Adidasa (np. długie i krótkie T-Shirts). Dzięki temu rozwiązaniu eliminuje się konieczność mocowania na ciele specjalnego oprzyrządowania. Części odzieży są wyposażone w specjalne nitki umożliwiające umieszczenie nadajnika. Powstałe w wyniku połączenia tej idei buty sportowe mierzą prędkość biegu oraz przebytą odległość za pomocą sensora. Dane odbiera zegar Polara, pokazując rytm pracy serca, pokonane odległości oraz prędkość. W związku z tym użytkownik otrzymuje wiązkę usługową tworzącą dodatkowe korzyści. Ponadto dane $\mathrm{z}$ treningu biegowego mogą zostać przeniesione do komputera i wprowadzone do portalu internetowego www.polarpersonaltrainer.com. Portal tworzy możliwość projektowania i kontrolowania własnego, indywidualnego treningu biegowego. Stanowi to pierwszy krok do budowy interakcji z nabywcami oferty usługowej poprzez ofertę kanału interakcji dla włączenia wiedzy użytkowników i informacji o konkretnych potrzebach dla przyszłych rozwiązań innowacyjnych firm. Możliwości interaktywnego hybrydowego tworzenia wartości są zatem otwarte. Wydaje się oczywiste dążenie do rozszerzenia systemu treningowego o dodatkowe, bogatsze oferty usługowe i rozbudowy możliwości interakcyjnych między poszczególnymi użytkownikami, ale również między użytkownikami a sferą badań i rozwoju u producentów. Celem takich działań jest wykorzystanie informacji dla potrzeb budowy strategicznego potencjału innowacji u producentów.

W podobny sposób firmy Nike oraz Apple połączyły siły w celu wytworzenia wspólnego produktu zwanego Nike+. Od jesieni 2006 roku można było kupić produkt ich wspólnego hybrydowego połączenia kluczowych kompetencji. „Jądro” produktu składało się ze sportowych butów „biegówek” Nike+, iPoda nano i urządzenia zwanego Nike+Sport Kit. W wewnętrznej podeszwie butów utworzono specjalne miejsce dla nadajnika. Dla potrzeb eksploatacji iPod nano wyposażono w odbiornik wraz z niezbędnym sofwarem. Dzięki urządzeniu Nike+ Sport Kit uzyskiwano bezprzewodowe połączenie do iPoda nano. Nowy hybrydowy produkt łączył sfery rozrywki i treningu sportowego. Wartość dodana dla klientów była wynikiem połączenia określonych funkcji. Użytkownik otrzymywał z nadajnika przekazywane na monitor informacje o czasie biegu, pokonanej 
drodze, spalonych kaloriach i prędkości oraz dodatkowo przez słuchawki, w czasie rzeczywistym, otrzymywał informacje zwrotne w trakcie treningu. Po jego zakończeniu użytkownik mógł podłączyć iPoda do komputera i zapisać dane dotyczące biegu. Przez aktywne połączenie internetowe dane te mogły być następnie przekazane na portal www.nikeplus.com. Tutaj użytkownicy śledzą swoje indywidualne dane z treningów, wymieniają poglądy bądź wirtualnie rywalizują. Ofertę hybrydową stanowi osobisty trener oraz swojego rodzaju system motywujący do uzyskiwania lepszych wyników w połączeniu z muzyką. W wyniku hybrydowego połączenia produktu, softwaru i usługi powstaje dla użytkowników nowa innowacyjna oferta z wartością dodaną. Dla oferentów natomiast powiązanie to oznacza przesunięcie granic innowacyjności. Nike poszerza świat sportu o dodatkowe przeżycia i efekty, a Apple uzupełnia świat pecetów i muzyki o osobisty efekt coachingu. Platforma interakcji dostarcza ponadto obu firmom bezpośrednio nowych informacji o rynku i potrzebach odbiorców. Dla użytkowników interakcja tworzy możliwość bezpośredniej artykulacji swoich potrzeb i pomysłów na ich rozwiązanie, wymiany poglądów i ich wirtualizacji. W ten sposób aktualna oferta hybrydowa tworzy podstawę dla kształtowania przyszłych ofert obydwu przedsiębiorstw i innych potencjalnych partnerów.

\section{PODSUMOWANIE}

Hybrydowe i interaktywne tworzenie wartości można przedstawić jako nową koncepcję zarządzania przedsiębiorstwami przemysłowymi w celu zwiększenia ich konkurencyjności na rynku. Oznacza ona jednocześnie nowe wyzwania dla logistyki, szczególnie gdy chodzi o jej funkcje integracyjno-koordynacyjne w ramach systemów metalogistycznych oraz wzrost znaczenia jej funkcji obsługowej dla klientów. Idea hybrydowego tworzenia wartości wymagać będzie jednak gruntownych studiów nad koniecznością zmiany logistycznych punktów ciężkości w sferze obsługi klienta oraz ściślejszej współpracy sfer logistyki i marketingu współpracujących przedsiębiorstw. Ten przymus weryfikacji zarządzania logistyką wynika wprost ze zmodyfikowanej oferty przedsiębiorstw przemysłowych; zamiast konkretnego produktu we właściwym miejscu, czasie oraz liczbie, oferuje się rozwiązywania konkretnych problemów dla ostatecznych klientów lub partnerów rynkowych, przy ich aktywnym włączeniu w tworzenie rozwiązań innowacyjnych (koncepcja Open Innovation). 


\section{BIBLIOGRAFIA}

Becker J., Krcmar H. (2008), Integration von Produktion und Dienstleistung - Hybride Wertschoepfung, ,Wirtschaftsinformatik” Nr. 3.

Bullinger H.-J. (1997), Dienstleistungen fuer das 21. Jahrhundert - Trends, Visionen und Perspektiven, [w:] H.-J., Bullinger (Hrsg.), Dienstleistungen fuer das 21. Jahrhundert, Schaffer Poeschel.

Bullinger H.-J. (1999), Entwicklung innovativer Dienstleistungen, [w:] Bullinger H.-J. (Hg.), Dienstleistungen - Innovation für Wachstum und Beschäftigung, Gabler Verlag, Wiesbaden.

Ernst E. (2007), Hybride Wertschoepfung: Ansaetze zur Integration von Produkt und Dienstleistung im Forschungsprogramm, „Innovationen mit Dienstleistungen”, Dezember.

Horst Wildemann beantwortet Fragen über Chancen von PoP in der deutschen Industrie. www.tcw.de/uploads/html/.../Betreibermodelle_Interview.pdf.

Korell M., Ganz W. (2000), Design hybrider Produkte - Der Weg vom Produkthersteler zum Problemloeser, [w:] H.-J. Bullinger (Hrsg.), Wettbewerbsfaktor Kreativitaet: Strategien, Konzepte und Werkzeuge zur Steigerung der Dienstleistunsperformance, Wiesbaden, Gabler.

Kowalak R., red. (2009), Rachunek kosztów cyklu życia produktu w zarządzaniu przedsiębiorstwem, Uniwersytet Ekonomiczny we Wrocławiu, Wrocław.

Lay G. (2003), Betreiben statt Verkaufen. Häufigkeit des Angebots von Betreibermodellen in der deutschen Investitionsgüterindustrie. Mitteilungen aus der Produktionsinnovationserhebung, Fraunhofer Institut, Systemtechnik und Innovationsforschung, Mai 2003, nr 29, www.isi.fraunhofer.de/isi-de/i/download/pi-mitteilungen/pi29.pdf.

Moeslein K. M., Koelling M. (2007), Interaktive hybride Wertschöpfung als Inno-vationsstrategie, Center for Leading Innovation \& Cooperation (CLIC), HHL - Leipzig Graduate School of Management, Leipzig.

Nippa M., Wienhold D., Piezonka S. (2007), Vom klassischen Produkt- zum Loesungsgeschaeft - Implikationen fuer eine Neugestaltung des Verguetungssystems im Vertrieb, Freiberger Arbeitspapiere 02, Technische Bergakademie Freiberg, Lehrstuhl für Unternehmensführung und Personalwesen, Freiberg.

G. Schmitz (2008), Der wahrgenommene Wert hybrider Produkte: Konzeptio nelle Grundlagen und Komponentem, Multikonferenz Wirtschaftsinformatik, GITO-Verlag, Berlin.

Subieta K.; Bazy danych i inżynieria oprogramowania. Wykład. www.ipipan.waw. $\mathrm{pl} / \sim$ subieta/wyklady/.../07\%20ODMG07.ppt.

Wertschaffung und Wertaneignung bei hybriden Produkten. Eine prozessorientierte Betrachtung (2007), Arbeitsbericht Nr. 03, des Lehrstuhls für Betriebswirtschaftslehre - Information, Organisation und Management der Technischen Universität, München.

Wildemann H. (2004), Produktionsorganisation. Handwörterbuch Unternehmensführung und Organisation, 4. Auflage, Schreyögg, v. Werder [Hrsg.]. 
Woźniak H. (2008), Ewolucja tańcuchów dostaw. Cz. II, „Logistyka”, nr 6. www.business-wissen.de/.../betreibermodell-kunden-bezahlen-nur-noch-fuer-den-service/-16.10.2008.

www.projekt-sprint.de.

\section{HYBRID PRODUCTS AS A CHALLENGE FOR LOGISTICS}

Abstract: Logistics needs to adjust to the changing conditions of managing, in particular, it needs to become an effective tool in supporting a company's competitiveness on the international market that is increasingly challenging. The purpose of the present paper is to indicate certain possibilities of supporting the competitiveness of manufacturing companies through developing and implementing hybrid products. They operate on a higher level of providing services and offer their customers individual solutions related to the purchase and use of products under specific market conditions. That requires on the part of manufacturers a completely new approach to building relationships with customers.

Keywords: customer service, services package, hybrid products, creating hybrid value, logistics. 
